\title{
PENERAPAN MODEL PEMBELAJARAN PROBLEM BASED LEARNING $(P B L)$ UNTUK MENINGKATKAN KEMAMPUAN PEMECAHAN MASALAH MATEMATIKA SISWA DI KELAS XI-IPA SMA ISLAM AL-ULUM TERPADU MEDAN
}

\author{
Tri Wulan Sari ${ }^{1}$ \\ ${ }^{1}$ Madrasah Aliah Negeri 1 Langkat
}

Balai Diklat Keagamaan Medan Jl. TB. Simatupang No. 122 Medan Telp. (061) 8456256

E-mail: triwulansari12@umsu.ac.ic Naskah diterima: 21 April 2021 Naskah Direvisi: 21-28 April 2021

Naskah disetujui: 30 April 2021 Website Journal: http://apicbdkmedan.kemenag.go.id

\begin{abstract}
ABSTRAK
Penelitian ini bertujuan untuk mengetahui: (1) Apakah penerapan model pembelajaran Problem Based Learning (PBL) dapat meningkatkan kemampuan pemecahan masalah matematika siswa pada materi pokok program linear. (2) Apakah penerapan model pembelajaran Problem Based Learning (PBL) dapat meningkatkan ketuntasan klasikal siswa pada materi pokok program linear. (3) respon apakah yang diberikan siswa terhadap penerapan model pembelajaran Problem Based Learning (PBL) pada materi program linear. Jenis penelitian ini adalah Penelitian Tindakan Kelas (Classroom Action Research). Subjek dalam penelitian ini adalah siswa kelas XI-IPA SMA Islam Al-Ulum Terpadu Medan T.A 2016/2017 yang terdiri atas 38 siswa sedangkan objek dalam penelitian ini adalah meningkatkan kemampuan pemecahan masalah matematika siswa pada materi pokok program linear dengan menerapkan model pembelajaran problem based learning di kelas XI-IPA SMA Islam Al-Ulum Terpadu Medan T.A 2016/2017.
\end{abstract}

Kata kunci: Kemampuan, Pemecahan Masalah, Matematika, PBL

\section{ABSTRACT}

The aim of this research is (1) to know the implementation strategy of Problem Based Learning (PBL) that is used to improve mathematically ability students in the Linear Progamming (2) to know the increasing of mathematically ability students in the Linear Progamming in class XI-IPA SMA Islam Al-Ulum Terpadu Medan T.A 2016/2017 after the implementation of Problem Based Learning (PBL) material Linear Progamming in class XI-IPA SMA Islam Al-Ulum Terpadu Medan T.A 2016/2017. Subjects in this research were students of class XI-IPA SMA Islam Al-Ulum Terpadu Medan T.A 2016/2017 totaling 38 students and the object of this study is used to improve mathematically ability students in the Linear Progamming in class XI-IPA SMA Islam Al-Ulum Terpadu Medan T.A 2016/2017. The research instrument used is observation, tests and documentation. From the test mathematically ability results, it can be concluded that the implementation strategy of Problem Based Learning $(P B L)$ that is used to improve mathematically ability students in the Linear Progamming in class XI-IPA SMA Islam Al-Ulum Terpadu Medan T.A 2016/2017.

Keywords: mathematically, ability Problem Solving, Problem Based Learning 


\section{PENDAHULUAN}

Pendidikan merupakan salah satu hal yang sangat penting dalam kehidupan. Sumber daya manusia (SDM) dapat meningkat dengan adanya pendidikan. Pendidikan akan mengarahkan proses berpikir seseorang yang dimulai dari taraf berpikir yang rendah menuju ke tingkat yang cemerlang. Sehingga pemikiran tersebut akan menghasilkan suatu pemahaman pada satu hal dan mampu mengubah tingkah laku seseorang tersebut. Hal ini lah yang akan menonjolkan suatu potensi dalam diri manusia.

Sinergi dengan makna pentingnya pendidikan di atas, maka untuk mencapai pengembangan potensi diri manusia ke arah yang lebih baik diperlukan adanya proses pembelajaran. Pembelajaran yang dimaksud bukan hanya mendapatkan hal yang baru yang mampu membuat seseorang awalnya tidak mengetahui menjadi mengetahui. Membuat seseorang melakukan kegiatan transfer ilmu dari luar kepada dirinya. Sebagaimana fungsi pendidikan nasional yang tercantum dalam Undang-Undang RI Nomor 20 Tahun 2003 Pasal 3 berikut:

Pendidikan Nasional berfungsi mengembangkan kemampuan dan membentuk watak serta peradaban bangsa yang bermartabat dalam rangka mencerdaskan kehidupan bangsa. Pendidikan bertujuan untuk mengembangkan potensi peserta didik agar menjadi manusia yang beriman dan bertakwa kepada Tuhan Yang Maha Esa, berakhlak mulia, sehat, berilmu, cakap, kreatif, dan mandiri.

Namun, pembelajaran tersebut akan mengandalkan pengalaman yang telah dimiliki sebelumnya dengan pengalaman yang baru ia dapatkan. Belajar merupakan proses untuk menciptakan hubungan antara sesuatu yang sudah dipahami dengan sesuatu yang baru. Sebagaimana didefinisikan Anthony Robbins (dalam Trianto, 2013: 15), "Belajar sebagai proses menciptakan hubungan antara sesuatu (pengetahuan) yang sudah dipahami dan sesuatu (pengetahuan) yang baru." Sehingga proses pembelajaran akan membutuhkan fakta sebelumnya yang akan dikembangkan dengan adanya proses berpikir menggunakan akal manusia.
Matematika adalah ilmu dasar yang berkembang sangat pesat baik materi maupun kegunaannya. Matematika merupakan salah satu pelajaran di sekolah yang dinilai cukup memegang peranan penting, termasuk pengaplikasiannya dalam kehidupan. Peranan matematika dalam kehidupan mencakup permasalahan-permasalahan yang dihadapi manusia dalam kehidupannya sehari-hari. Matematika akan mampu membentuk manusia berpikir logis, kritis, inovatif dan ilmiah sebagaimana dijelaskan oleh Cornelius (dalam Abdurrahman, 2009: 253) mengemukakan bahwa perlunya matematika diajarkan kepada siswa karena:

(1) Selalu digunakan dalam segi kehidupan, (2) semua bidang studi memerlukan keterampilan matematika yang sesuai, (3) merupakan sarana komunikasi yang kuat, singkat, dan jelas, (4) dapat digunakan untuk menyajikan informasi dalam berbagai cara, (5) meningkatkan kemampuan berpikir logis, ketelitian, dan kesadaran, dan (6) memberikan kepuasan terhadap usaha yang menantang.

Namun, banyak kalangan yang menganggap bahwa matematika merupakan pelajaran yang paling sulit. Dan banyak orang berusaha untuk menghindari pelajaran matematika. Akan tetapi, karena permasalahan dalam kehidupan sehari-hari tidak terlepas dari matematika, maka setiap orang harus mempelajarinya. Hal ini sesuai dengan pendapat yang dikemukakan oleh Abdurrahman (2012: 202), "Banyak orang yang memandang matematika sebagai bidang studi yang paling sulit, meskipun demikian semua orang harus mempelajarinya karena merupakan sarana untuk memecahkan masalah kehidupan sehari-hari”.

Berdasarkan kutipan di atas, dapat disimpulkan bahwa matematika dapat meningkatkan kemampuan seseorang untuk berpikir logis, teliti, kesadaran dan penuh perhitungan yang nantinya akan bermanfaat sebagai sarana dalam memecahkan masalah dalam kehidupan sehari-hari. Maka dari itu, tidak diragukan lagi bahwa setiap anak didik harus mendapat pelajaran matematika di sekolah. Jadi, penting bagi kita terutama siswa menyadari pentingnya matematika sebagai subjek yang sangat penting dalam peradaban 
manusia, terutama dalam sistem pendidikan di seluruh dunia. Hal ini terlihat dari matematika merupakan bidang studi yang dipelajari oleh semua siswa dari tingkat Sekolah Dasar (SD) hingga di perguruan tinggi.

Mempertimbangkan

pentingnya

matematika dalam mengembangkan potensi yang ada dalam diri manusia maka seharusnya matematika menjadi mata pelajaran yang diminati oleh setiap siswa. Namun, matematika justru menjadi mata pelajaran yang banyak ditakuti oleh siswa. Selama ini siswa sudah lebih dahulu menganggap bahwa pelajaran matematika itu merupakan pelajaran yang sulit karena menggunakan simbol dan lambang yang dimaknai dengan rumus matematika. Hal ini juga dikemukakan oleh Abdurrahman (2009: 252) bahwa, "Dari berbagai bidang studi yang diajarkan di sekolah, matematika merupakan bidang studi yang dianggap paling sulit oleh para siswa, baik yang tidak berkesulitan belajar dan lebih-lebih bagi siswa yang berkesulitan belajar."

Kesulitan siswa tersebut terletak pada kemampuan siswa menyelesaikan soal cerita matematika serta kurangnya petunjuk langkahlangkah yang harus ditempuh dalam membuat kalimat matematika. Kesulitan belajar matematika mengakibatkan kemampuan pemecahan masalah siswa menjadi rendah. Siswa cenderung menghafalkan konsep-konsep matematika dan hanya mencatat. Meskipun mereka kurang memahami apa yang mereka hapal dan catat tersebut, sehingga sewaktu siswa diberikan masalah matematika mereka tidak mengerti bagaimana cara untuk menyelesaikannya dengan konsep yang telah mereka hapal.

Hal tersebut dikemukakan oleh Sriyanti (2013: 149) bahwa, "Faktor anak internal yang menjadi penyebab kesulitan yaitu kebiasaan belajar yang salah, seperti belajar bila akan ujian saja, belajar sekedar menghafal tanpa mengerti maknanya, mempunyai kebiasaan menyontek."

Kesulitan belajar yang dialami oleh siswa tersebut akan membawa pengaruh juga pada kemampuan pemecahan masalah matematika bagi siswa. Kesulitan belajar tersebut akan mengakibatkan kemampuan pemecahan masalahnya menjadi rendah, tentu hasil belajar yang diperoleh juga tidak seperti yang diinginkan.

Berdasarkan observasi yang dilakukan oleh peneliti pada siswa kelas XI-IPA SMA Islam Al-Ulum Terpadu Medan pada 23 Februari 2016 diperoleh bahwa tingkat kemampuan pemecahan masalah matematika siswa masih rendah. Hal ini terlihat dari hasil tes kemampuan awal materi Sistem Persamaan dan Pertidaksamaan Linear Dua Variabel yang diberikan kepada siswa bahwa dari 38 siswa yang mengikuti tes hanya sebanyak 10 siswa atau sekitar 26,31\% yang memperoleh nilai di atas KKM (Kriteria Ketuntasan Minimum) dan 28 siswa atau sekitar 73,68\% yang memperoleh nilai di bawah KKM. Adapun KKM untuk bidang studi matematika di SMA Islam AlUlum Terpadu Medan yaitu 7,5.

Setiap siswa di kelas XI-IPA SMA Islam Al-Ulum Terpadu Medan memiliki usaha pemecahan masalah yang berbeda-beda. Hal ini terlihat pada lembar hasil pekerjaan siswa terhadap persoalan materi Sistem Persamaan dan Pertidaksamaan Linear Dua Variabel yang telah diberikan. Masing-masing dari siswa memiliki caranya tersendiri untuk menyelesaikan setiap soal yang diberikan, pada pemahaman masalah mereka ada yang mampu memahami permasalahan, merancang suatu strategi penyelesaian masalah, melaksanakan strategi atau melakukan perhitungan dan menarik kesimpulan dari penyelesaian masalah yang telah dilakukan. Namun, masih banyak juga siswa yang belum mampu memahami permasalahan dengan baik.

Hasil pekerjaan siswa pada bagian perencanaan strategi penyelesaian soal memperlihatkan bahwa sebagian besar siswa tidak menuliskan model matematika yang relevan dengan masalah, menulis model matematika yang benar tetapi tidak lengkap. Pada tahap pelaksanaan rencana strategi penyelesaian, hanya sebagian kecil siswa yang menggunakan langkah-langkah penyelesaian dengan benar dan hasilnya juga benar, sebagian lainnya masih menggunakan langkah-langkah penyelesaian yang mengarah ke solusi yang benar tetapi tidak lengkap dan hasil akhirnya salah.

Hasil wawancara yang dilakukan peneliti kepada guru yang mengajar bidang studi matematika di kelas XI- IPA SMA Islam 
Al-Ulum Terpadu Medan, menunjukkan bahwa penyebab rendahnya kemampuan pemecahan masalah matematika siswa yaitu daya mengingat siswa yang rendah serta minat membaca siswa kurang. Hal ini terlihat dari siswa yang mampu mengingat materi dan konsepnya ketika pembelajaran materi itu masih berlangsung. Ketika penyampaian materi tersebut sudah berlalu kemudian dilanjut dengan materi yang lain, maka siswa akan mengalami kesulitan kembali menelaah permasalahan pada materi yang lalu, sehingga perlu untuk diingatkan kembali. Selain itu, terlihat bahwa siswa hanya menggunakan buku paket yang telah dibagikan dari sekolah saja tanpa mau mencari dari sumber lain. Hanya sebagian kecil saja siswa yang mau mencari dari sumber lain.

Penyebab lain yang mengakibatkan rendahnya kemampuan pemecahan masalah matematika yaitu karena siswa hanya beracuan pada penghafalan rumus saja. Sedangkan untuk penerapannya pada soal masih kurang. Siswa hanya berorientasi pada penggunaan rumus dan menghitung. Mengakibatkan mereka akan kesulitan ketika menemui soal yang membutuhkan penalaran dan kemampuan pemecahan masalah matematika seperti pada materi program linear. Para siswa akan sangat mudah menghitung menggunakan rumus yang mereka hafal, namun untuk mengarahkan soal pada tahap-tahap pemecahan masalah matematikanya masih sangat sulit.

Guru biasanya menerapkan model pembelajaran yang berorientasi pada permainan seperti jigsaw, TGT dan lain sebagainya Untuk mengatasi kendala-kendala yang telah tercantum di atas. Serta membantu siswa untuk mengarahkan pemahaman mereka pada penerapan materi pelajaran yang sedang berlangsung pada kehidupan sehari-hari. Namun, model pembelajaran ini tidak dapat dilakukan terus menerus terhadap semua materi, mengingat banyaknya materi yang membutuhkan pemahaman dan penanaman konsep.

Peneliti juga melakukan wawancara kepada beberapa siswa kelas XI- IPA SMA Islam Al-Ulum Terpadu Medan dan diperoleh penyebab rendahnya kemampuan pemecahan masalah matematika yaitu sulitnya penerapan rumus-rumus matematika dan sulit untuk mengubah soal cerita menjadi model matematika, seperti pada materi sistem persamaan atau pertidaksamaan linear dua variabel, siswa kesulitan menggunakan model matematika untuk menentukan daerah penyelesaiannya pada soal yang berbentuk soal cerita. Mereka lebih menyukai persoalan matematika yang berbentuk langsung perhitungan dari pada soal yang berbentuk cerita, karena soal cerita lebih rumit, membutuhkan pemahaman yang tinggi, dan sering membuat penafsiran yang banyak untuk menerapkan rumus dan model matematikanya. Mereka menginginkan adanya cara atau metode yang lebih mudah dalam memahami pembelajaran matematika. Terlebih pada cara yang mengarahkan siswa memahami penerapan tahapan-tahapan pemecahan masalah matematika.

Berdasarkan hasil observasi dan wawancara yang dilakukan peneliti tersebut, maka untuk mengatasi permasalahan kemampuan pemecahan masalah di atas dibutuhkan suatu model pembelajaran yang mampu menciptakan suasana menyenangkan. Salah satu cara untuk menggembangkan kemampuan pemecahan masalah matematika siswa yaitu dengan suatu model pembelajaran yang mengutamakan keaktifan siswa sehingga mampu mengembangkan kemampuan pemecahan masalah matematikanya. Selain itu diperlukan suatu model pembelajaran yang menyajikan tugas-tugas dalam bentuk masalah karena dengan adanya masalah maka siswa akan berusaha untuk mencari solusinya dengan berbagai ide sehingga kemampuan berpikir siswa benar-benar dioptimalkan melalui proses pemecahan masalah tersebut. Oleh karena itu perlu diterapkannya suatu model pembelajaran yang dapat meningkatkan kemampuan siswa dalam memahami dan dapat meningkatkan kemampuan pemecahan masalah matematika siswa. Model pembelajaran yang diharapkan yaitu interaktif dan mengarahkan siswa untuk lebih paham dalam langkah-langkah pemecahan soal matematika, terlebih untuk soal cerita. Dari beberapa referensi yang diperoleh, peneliti memilih menerapkan model PBL (Problem Based Learning).

Model pembelajaran problem based learning, memusatkan pembelajaran pada masalah yang dipilih. Sehingga, pelajar tidak 
saja mempelajari konsep-konsep yang berhubungan dengan masalah tetapi juga metode ilmiah untuk memecahkan masalah tersebut. Model pembelajaran problem based learning digunakan untuk merancang kemampuan berpikir tingkat tinggi dengan situasi berorientasi pada masalah. Dengan model ini siswa dapat berpikir kritis dan lebih kreatif serta dapat menjajaki bidang-bidang baru dan menghasilkan penemuan-penemuan baru. Karena hal itu lah yang akan yang menjadi tujuan dari kemampuan pemecahan masalah siswa yang akan diasah dengan menggunakan model pembelajaran ini. Sumiati dan Asra (2013: 141) mengemukakan,

Kemampuan memecahkan masalah memerlukan proses berpikir. Jika masalah itu berhasil dipecahkan berarti siswa mempelajari sesuatu yang baru. Oleh karena itu kemampuan siswa dalam berpikir seperti mengamati, bertanya dan berkomunikasi dan berinteraksi dengan lingkungannya perlu terus ditingkatkan. Pemikiran siswa diarahkan pada hal-hal yang menuntut kemampuan mencari jawaban sebanyak mungkin terhadap persoalan yang dihadapinya. Siswa dirancang berpikir kreatif dan dapat menjajaki bidangbidang baru dan menghasilkan penemuanpenemuan baru.

Model pembelajaran problem based learning (PBL) akan mengarahkan siswa untuk merasa tertarik dan termotivasi dalam menyelesaikan permasalahan yang diberikan, sebab permasalahan tesebut merupakan permasalahan nyata yang membutuhkan penyelesaian nyata pula. Menurut Trianto (2013: 90) menyatakan bahwa:

Model pembelajaran problem based learning merupakan suatu model pembelajaran yang didasarkan pada banyaknya permasalahan yang membutuhkan penyelidikan yang autentik yakni penyelidikan yang membutuhkan penyelesaian nyata dari permasalahan yang nyata.

Model problem based learning (PBL) juga memiliki potensi yang amat besar untuk membuat pengalaman belajar yang lebih menarik dan bermakna. Selain itu PBL juga memfasilitasi peserta didik untuk berinvestigasi, memecahkan masalah, bersifat students centered, dan menghasilkan produk nyata berupa hasil proyek. Peserta didik akan masuk ke dalam sebuah kompetisi bersama kelompoknya, dan masing-masing kelompok bersaing untuk menjadi yang paling unggul di antara yang lain. Pada saat yang bersamaan, peserta didik merasa senang dalam melakukan proyek, mencoba sesuatu yang berbeda dan membuat mereka merasa memiliki pengetahuan dan dihargai.

Pandangan-pandangan tersebut yang akhirnya menyimpulkan bahwa model pembelajaran problem based learning (PBL) akan memfasilitasi keberhasilan kemampuan pemecahan masalah-masalah nyata yang terjadi sehari-hari dengan penyelesaian nyata, menjajaki bidang-bidang baru dan menghasilkan penemuan-penemuan baru, serta keterampilan interpersonal dengan lebih baik dibandingkan pendekatan yang lain.

Adapun rumusan masalah dalam penelitian ini adalah: 1) Apakah penerapan model pembelajaran Problem Based Learning (PBL) dapat meningkatkan kemampuan pemecahan masalah matematika siswa pada materi pokok program linear di kelas XI-IPA SMA Islam AlUlum Terpadu Medan T.A 2016/2017?; 2) Apakah penerapan model pembelajaran Problem Based Learning (PBL) dapat meningkatkan ketuntasan klasikal siswa pada materi pokok program linear di kelas XI-IPA SMA Islam Al-Ulum Terpadu Medan T.A 2016/2017?; 3. Respon apakah yang diberikan siswa kelas XI-IPA SMA Islam Al-Ulum Terpadu Medan T.A 2016/2017 terhadap penerapan model pembelajaran Problem Based Learning $(P B L)$ pada materi program linear?

Tujuan penelitian ini Antara lain: 1) Mengetahui apakah penerapan model pembelajaran Problem Based Learning (PBL) dapat meningkatkan kemampuan pemecahan masalah matematika siswa pada materi pokok program linear di kelas XI-IPA SMA Islam AlUlum Terpadu Medan T.A 2016/2017; 2) Mengetahui apakah penerapan model pembelajaran Problem Based Learning (PBL) dapat meningkatkan ketuntasan klasikal siswa pada materi pokok program linear di kelas XIIPA SMA Islam Al-Ulum Terpadu Medan T.A 2016/2017?; 3) Mengetahui respon apakah yang diberikan siswa kelas XI-IPA SMA Islam Al-Ulum Terpadu Medan T.A 2016/2017 terhadap penerapan model pembelajaran 
Problem Based Learning (PBL) pada materi program linear.

Hasil dari pelaksanaan Penelitian Tindakan Kelas ini akan memberikan manfaat bagi perorangan atau institusi di bawah ini: 1) Bagi sekolah tempat penelitian, sebagai bahan pertimbangan dalam pengembangan dan penyempurnaan program pengajaran matematika di sekolah.; 2) Bagi guru, dapat memperluas wawasan pengetahuan mengenai model pembelajaran dalam membantu siswa guna meningkatkan kemampuan pemecahan masalah matematika; 3) Bagi siswa, model pembelajaran Problem Based Learning (PBL) dapat membantu siswa untuk meningkatkan kemampuan pemecahan masalah matematika; 4) Bagi peneliti, sebagai bahan informasi sekaligus sebagai bahan pegangan dalam menjalankan tugas pengajaran sebagai calon tenaga pengajar di masa yang akan datang.

\section{METODOLOGI PENELITIAN}

Penelitian ini dilakukan di SMA Islam Al-Ulum Terpadu Medan yang beralamat di Jl. Tuasan Medan. Alasan pemilihan lokasi ini karena telah teridentifikasi rendahnya kemampuan pemecahan masalah matematika siswa kelas XI-IPA.

Subjek dalam penelitian ini adalah siswa kelas XI-IPA SMA Islam Al-Ulum Terpadu Medan T.A 2016/2017 yang terdiri atas 38 siswa.

Objek dalam penelitian ini adalah meningkatkan kemampuan pemecahan masalah matematika siswa pada materi pokok program linear dengan menerapkan model pembelajaran problem based learning di kelas XI-IPA SMA Islam Al-Ulum Terpadu Medan T.A 2016/2017.

Jenis penelitian ini adalah penelitian tindakan kelas (Classroom Action Research) yang dilakukan secara kolaboratif dengan guru kelas. Pendekatan yang digunakan adalah pendekatan kuantitatif yang berguna untuk mengungkapkan kesulitan belajar siswa dalam mempelajari materi pembelajaran Program Linear, serta mengatasi kesulitan-kesulitan tersebut sebagai upaya untuk meningkatkan kemampuan pemecahan masalah matematika siswa dengan penerapan model pembelajaran problem based learning pada materi program linear di kelas XI-IPA SMA Islam Al-Ulum Terpadu Medan T.A 2016/2017.

Alat yang digunakan dalam pengumpulan data pada penelitian ini adalah berupa tes, observasi, wawancara dan kuesioner.

Untuk memperoleh data yang diperlukan dalam penelitian ini digunakan objektif tes sehingga diketahui sejauh mana tingkat kemampuan pemecahan masalah matematika siswa. Tes yang diberikan disesuaikan dengan tujuan pembelajaran yang ingin dicapai. Tes ini terdiri dari tes kemampuan awal dan tes kemampuan pemecahan masalah. Sebelum diberikan kepada siswa, tes yang telah disusun terlebih dahulu divalidkan oleh validator. Jika dikatakan ada peningkatan maka itu berarti kemampuan pemecahan masalah matematika siswa mengalami perubahan yang lebih baik.

Pengamatan partisipatif merupakan kegiatan penting dalam setiap penelitian yang menganjurkan peneliti berinteraksi dengan subjek yang diteliti, termasuk dalam penelitian tindakan kelas. Maka dari itu untuk memperoleh data dilapangan diperlukan adanya observasi.

Observasi yang dilakukan merupakan pengamatan terhadap seluruh kegiatan pembelajaran dan perubahan yang terjadi pada saat dilakukannya pemberian tindakan. Pengamatan dilakukan oleh peneliti dibantu oleh guru mata pelajaran terhadap hal-hal yang terjadi pada saat pemberian tindakan dengan tujuan agar diketahui apakah kondisi belajar sudah sesuai dengan rencana pembelajaran.

Wawancara dapat diartikan sebagai proses bertemu muka antara para guru-peneliti dan para siswa, yang direncanakan untuk mendapatkan informasi yang diperlukan. Menurut Sudjana (2010: 68) bahwa: "Ada tiga aspek yang harus diperhatikan dalam melaksanakan wawancara, yakni (a) tahap awal pelaksanaan wawancara; (b) penggunaan pertanyaan, dan (c) pencatatan hasil wawancara."

Dalam penelitian tindakan kelas, wawancara yang baik adalah menggunakan wawancara yang mendalam. Dalam penelitian ini wawancara dilaksanakan oleh peneliti sebelum penelitian yaitu kepada guru mata 
pelajaran matematika dan beberapa siswa kelas XI-IPA SMA Islam Al-Ulum Terpadu Medan.

Kuesioner merupakan teknik pengumpulan data yang dilakukan dengan cara memberi seperangkat pertanyaan atau pernyataan tertulis kepada responden untuk dijawab. Kuesioner ini dapat berupa pertanyaan atau pernyataan terbuka atau tertutup. Dengan adanya kontak langsung antara peneliti dengan responden akan menciptakan kondisi yang cukup baik, sehingga responden dengan sukarela akan memberikan data objektif, cepat dan tepat.

Kuesioner (angket) diberikan kepada siswa kelas XI-IPA SMA Islam Al-Ulum Terpadu Medan setelah penerapan model pembelajaran problem based learning dilakukan. Hal ini digunakan untuk mengetahui respon siswa terhadap penerapan model pembelajaran problem based learning pada materi pokok program linear.

Analisis dilakukan melalui tiga tahap, yaitu reduksi data, paparan data, dan penarikan kesimpulan. Data-data yang diperoleh berupa hasil tes belajar siswa, hasil observasi guru (peneliti), dan hasil observasi kegiatan siswa akan direduksi agar data tersebut lebih sederhana dengan cara mengelompokkan datadata (hasil tes belajar siswa, hasil observasi guru (peneliti), dan hasil observasi kegiatan siswa) dalam beberapa kategori kemudian mengorganisasikannya sehingga diperoleh informasi yang bermakna. Kegiatan inti ini bertujuan untuk melihat kelemahan siswa maupun guru dalam pembelajaran dan tindakan apa yang dilakukan untuk memperbaiki kelemahan tersebut. Setelah data hasil tes belajar siswa, hasil observasi guru (peneliti), dan hasil observasi kegiatan siswa direduksi, maka data tersebut dipaparkan dalam bentuk naratif, tabel, atau diagram, agar data tersebut lebih jelas dan mudah dipahami. Sehingga dapat memberikan gambaran jelas tentang proses dan hasil tindakan yang dilakukan.

Untuk membuat kesimpulan hasil penelitian yang telah dipaparkan akan dibandingkan dengan teori yang telah dikemukakan. Dari kegiatan ini akan disimpulkan apakah kemampuan pemecahan masalah siswa telah meningkat, kemudian bagaimana tingkat penguasaan siswa dan hasil observasi terhadap guru. Pada kegiatan inilah dapat diketahui apakah hasil yang diperoleh memenuhi indikator keberhasilan.

\section{HASIL DAN PEMBAHASAN PENELITIAN}

Berdasarkan hasil observasi kegiatan pembelajaran siswa dan analisis data pada tes kemampuan pemecahan masalah yang dilakukan oleh peneliti diperoleh bahwa kemampuan pemecahan masalah matematika siswa pada materi pokok program linear mengalami peningkatan dengan diterapkannya model problem based learning. Pelaksanaan pembelajaran berdasarkan hasil observasi guru bidang studi terhadap pembelajaran yang dilakukan oleh peneliti juga mengalami peningkatan sebesar 0,39 yaitu dari 2,71 (baik) pada siklus I menjadi 3,10 (baik) pada siklus II.

Berdasarkan tes kemampuan pemecahan masalah yang diberikan di akhir siklus I dan siklus II diperoleh bahwa kemampuan siswa dalam memecahkan masalah pada soal-soal yang diberikan mengalami peningkatan. Hasil ini dapat dilihat berdasarkan tercapainya tujuan penelitian, antara lain: Mengetahui apakah kemampuan pemecahan masalah matematika siswa di kelas XI-IPA SMA Islam Al-Ulum Terpadu Medan T.A 2016/2017 dapat meningkat setelah dilakukan penerapan model problem based learning. Penerapan model problem based learning dapat meningkatkan kemampuan pemecahan masalah matematika siswa di kelas XI-IPA SMA Islam Al-Ulum Terpadu Medan T.A 2016/2017.

Berdasarkan pada penjabaran data tersebut diperoleh bahwa kemampuan pemecahan masalah matematika siswa mengalami peningkatan yang signifikan. Meskipun terdapat beberapa siswa yang mengalami penurunan persentase kemampuan pemecahan masalah, namun persentase ratarata kemampuan pemecahan masalah matematika siswa meningkat sebesar $13,20 \%$ dari $68,16 \%$ pada siklus I menjadi $81,36 \%$ pada siklus II.

Mengetahui apakah ketuntasan klasikal siswa kelas XI-IPA SMA Islam Al-Ulum Terpadu Medan T.A 2016/2017 dapat meningkat setelah dilakukan penerapan model problem based learning pada materi pokok program linear. Penerapan model problem 
based learning pada materi pokok program linear dapat meningkatkan ketuntasan klasikal siswa kelas XI-IPA SMA Islam Al-Ulum Terpadu Medan T.A 2016/2017.

Berdasarkan pada penjabaran peningkatan persentase ketuntasan klasikal di atas diperoleh bahwa persentase ketuntasan klasikal kemampuan pemecahan masalah matematika siswa mengalami peningkatan yang signifikan. Besar peningkatan persentase ketuntasan klasikal yaitu 31,58\% dari 57,89\% pada siklus I menjadi $89,47 \%$ pada siklus II. Karena telah tercapainya indikator keberhasilan yaitu persentase ketuntasan klasikal lebih besar atau sama dengan $85 \%$ maka penelitian ini berhasil.

Mengetahui respon siswa kelas XI-IPA SMA Islam Al-Ulum Terpadu Medan T.A 2016/2017 terhadap model problem based learning pada materi pokok program linear.

Berdasarkan perhitungan skor respon masing-masing siswa diperoleh bahwa dari 38 siswa, 29 siswa $(76,32 \%)$ memiliki respon positif terhadap penerapan model problem based learning pada materi pokok program linear sedangkan 9 siswa $(23,68 \%)$ memiliki respon negatif. Hal ini berarti hampir seluruhnya siswa kelas XI-IPA SMA Islam AlUlum Terpadu Medan T.A 2016/2017 memberi respon positif terhadap model problem based learning.

Pembelajaran dengan menerapkan model problem based learning dapat meningkatkan kemampuan pemecahan masalah matematika siswa. Pembelajaran tersebut berpusat pada siswa untuk mengkontruksikan pengetahuan secara sendiri dan dengan bantuan lingkungan sosial budayanya. Sedangkan guru lebih ditekankan sebagai fasilitator. Sehingga pembelajaran bersifat aktif dan dinamis.

Berdasarkan hasil analisis penelitian dan kajian teori di atas, maka terbukti benar bahwa menerapkan model problem based learning tepat digunakan untuk meningkatkan kemampuan pemecahan masalah matematika siswa pada materi pokok program linear. Sebagai acuan, peneliti membandingkan penelitian ini dengan penelitian terdahulu yang relevan yakni penelitian yang dilakukan oleh Fadlillah (Tahun 2014). Beliau menyimpulkan bahwa, setelah pembelajaran problem based learning dilaksanakan, ternyata dapat meningkatkan kemampuan pemecahan masalah matematika siswa serta pembelajaran problem based learning ini menjadikan siswa sebagai subjek dan berinisiatif sendiri dalam kegiatan pembelajaran.

Berdasarkan penelitian yang relevan di atas, peneliti menyimpulkan bahwa hasil penelitian terdahulu yaitu pembelajaran yang menerapkan problem based learning memiliki hasil yang lebih baik dari pada sebelum dilaksanakan proses pembelajaran tersebut. Secara umum, penerapan model problem based learning dapat menjadi sebuah alternatif untuk meningkatkan kemampuan pemecahan masalah matematika siswa. Hasil temuan peneliti yang relevan tersebut menguatkan temuan peneliti bahwa dengan menerapkan model problem based learning dapat meningkatkan kemampuan pemecahan masalah matematika siswa pada materi program linear di kelas XIIPA SMA Islam Al-Ulum Terpadu Medan. Berdasarkan perbandingan penelitian terdahulu dengan penelitian yang dilakukan peneliti, menunjukkan bahwa langkah-langkah dalam menerapkan model problem based learning merupakan perangkat penting yang mempengaruhi kemampuan pemecahan masalah matematika siswa.

Namun dalam pelaksanaan penelitian, peneliti menemukan banyak kelemahankelemahan sehingga dalam menerapkan model problem based learning tidak menjadikan seluruh siswa memperoleh nilai tinggi. Adapun kelemahan yang peneliti temukan selama proses pembelajaran berlangsung yaitu: 1) Siswa belum terbiasa dengan menerapkan model problem based learning sehingga ada siswa yang kurang serius dalam mengikuti pembelajaran, serta siswa belum berani dalam menyampaikan pendapat atau ide-ide.; 2) Lingkungan kelas yang tidak mendukung terutama bagi siswa yang sulit menerima atau memahami pelajaran yang disampaikan.

Dengan demikian kepada peneliti selanjutnya agar memperbaiki semua kekurangan atau kelemahan peneliti dalam penelitian selanjutnya sehingga dapat memperoleh hasil yang lebih baik lagi.

\section{SIMPULAN}


Berdasarkan hasil penelitian dan pembahasan diperoleh beberapa kesimpulan sebagai berikut:

1. Strategi penerapan model Problem Based Learning yaitu:

a. Memaksimalkan diskusi kelompok dengan memberikan pengawasan yang lebih pada kelompok yang belum maksimal dalam proses diskusi yang dilakukan pada fase membimbing kelompok bekerja.

b. Memberikan LAS kepada setiap siswa agar lebih mudah dalam berdiskusi yang dilakukan pada fase mengoorganisasikan siswa ke dalam kelompok belajarnya.

c. Memberikan applause bagi siswa atau kelompok yang maju mempresentasikan hasil diskusinya, bagi siswa yang bertanya maupun bagi siswa yang member tanggapan terhadap presentasi kelompok penyaji yang dilakukan pada fase memberikan penghargaan. Hal ini bertujuan agar keaktifan siswa dalam pembelajaran dapat meningkat.

2. Penerapan model problem based learning dapat meningkatkan kemampuan pemecahan masalah matematika siswa kelas XI-IPA SMA Islam Al-Ulum Terpadu Medan T.A. 2016/2017 pada materi pokok program linear. Hal ini didasarkan pada peningkatan persentase rata-rata hasil tes kemampuan pemecahan masalah matematika siswa sebesar 13,20\% dari $68,16 \%$ (Cukup Baik) pada tes kemampuan pemecahan masalah I menjadi $81,36 \%$ (Baik) pada tes kemampuan pemecahan masalah II setelah diadakan upaya perbaikan dalam proses pembelajaran.

3. Penerapan model problem based learning dapat meningkatkan ketuntasan klasikal siswa kelas XI-IPA SMA Islam Al-Ulum Terpadu Medan T.A. 2016/2017 pada materi pokok program linear. Hal ini didasarkan pada jumlah siswa yang mencapai ketuntasan belajar meningkat sebesar 12 siswa $(31,58 \%)$ yaitu pada siklus I adalah 22 siswa $(57,89 \%)$ menjadi 34 siswa $(89,47 \%)$ pada siklus II setelah diadakan upaya perbaikan dalam proses pembelajaran.

4. Respon siswa terhadap model problem based learning positif dengan rata-rata 3,11 . Hal ini berdasarkan perhitungan skor respon masing-masing siswa yaitu dari 38 siswa, 29 siswa $(76,32 \%)$ memiliki respon positif terhadap model problem based learning yang diterapkan pada mata pelajaran matematika materi pokok program linear, sedangkan 9 siswa $(23,68 \%)$ memiliki respon negatif. Berarti hampir seluruhnya siswa kelas XI-IPA SMA Islam Al-Ulum Terpadu Medan T.A. 2016/2017 memiliki respon positif terhadap model problem based learning.

\section{SARAN}

Adapun saran-saran yang diajukan peneliti berdasarkan hasil penelitian, pembahasan dan kesimpulan adalah sebagai berikut:

1. Kepada guru matematika kelas XI-IPA SMA Islam Al-Ulum Terpadu Medan T.A. 2016/2017 disarankan menerapkan model pembelajaran problem based learning agar dapat meningkatkan kemampuan pemecahan masalah matematika siswa. Lebih tegas dalam menegur siswa yang kurang kondusif dalam pembelajaran, lebih banyak memberikan motivasi dan arahan kepada siswa mengenai manfaat pembelajaran matematika bagi kehidupannya di masa yang akan datang, tidak jenuh dalam mengulangi kembali intisari pelajaran sebelumnya guna keberhasilan tujuan pembelajaran dan melakukan perombakan kelompok yang heterogen berdasarkan hasil kemampuan pemecahan masalah matematika dan keaktifan siswa.

2. Bagi peneliti lanjutan yang ingin melakukan penelitian sejenis disarankan untuk menyediakan alokasi waktu yang lebih banyak dalam membuat maupun menyempurnakan media pembelajaran serta memperhatikan kelemahan-kelemahan yang ada pada peneliti, sehingga penelitian yang dilakukan semakin membaik.

\section{DAFTAR PUSTAKA}


Abdurrahman, Mulyono. 2012. Anak Berkesulitan Belajar: Teori, Diagnosis, dan Remediasinya. Jakarta: Rineka Cipta.

Abdurrahman, Mulyono. 2009. Pendidikan bagi Anak Berkesulitan Belajar. Jakarta : Rineka Cipta.

An-Nabhani, Taqiyuddin. 2014. Peraturan Hidup dalam Islam (Edisi Mu'tamadah). Jakarta: Hizbut Tahrir Indonesia.

Asri, Ramadani. 2013. Upaya Meningkatkan Kemampuan Pemecahan Masalah Matematika Siswa dengan Model Problem Based Learning pada Materi Pokok Aritmatika Sosial Kelas VII SMP Swasta Ampera Batang Kuis Tahun Ajaran 2012/2013. Medan : Universitas Negeri Medan, Skripsi, FMIPA, Unimed. Cunayah, Cucun dan Etsa Indra Irawan. 2013. 1700 Bank Soal Bimbingan Pemantapan Matematika untuk SMA/MA. Bandung: Yrama Widya.

Fakultas Matematika dan Ilmu Pengetahuan Alam Universitas Negeri Medan. 2012. Pedoman Penulisan Proposal dan Skripsi Mahasiswa Program Studi Kependidikan FMIPA Universitas Negeri Medan. Medan : FMIPA Unimed.

Fauziah, Anna. 2010. Peningkatan Kemampuan Pemahaman dan Pemecahan Masalah Matematika Siswa AMP Melalui Strategi REACT (Relating, Expperiencing, Applying, Cooperating, Transfering). Forum Kependidikan, 30 (1).

Firdaus. 2009. Kemampuan Pemecahan Masalah Matematika (http://madfirdaus.wordpress.com/2009/1 1/23/kemampuan-pemecahan-masalahmatematika/) (diakses 19 Februari 2016)

Hoseana. 2012. Sukses Juara Olimpiade Matematika. Jakarta: PT. Grasindo.

Hudojo, Herman. 2001. Pengembangan Kurikulum dan Pembelajaran Matematika. Malang: Universitas Negeri Malang.

Kusumawati dkk. 2012. Pembelajaran Program Linear Berkarakteristik Kewirausahaan untuk Meningkatkan Kemampuan Komunikasi Matematik. [online] Unnes Journal of Mathematics Education Research. Ngisor Semarang 50233. ISSN 2252 - 6455
Polya, George. 1973. How to Solve It. New Jersey: Princeton University Press.

Rusman. 2013. Model-Model Pembelajaran Mengembangkan Profesionalisme Guru. Jakarta : Rajawali Pers.

Sanjaya, Wina. 2014. Strategi Pembelajaran Berorientasi Standar Proses Pendidikan. Jakarta : Kencana.

Sihombing, W.L dan Ika Sartika. 2013. Telaah Kurikulum (Pendidikan Matematika Sekolah). Medan : Universitas Negeri Medan.

Soegito, dkk. 2003. Pendidikan Pancasila. Semarang : Uness Press.

Sriyanti, Lilik. 2013. Psikologi Belajar. Yogyakarta : Ombak.

Sudjana, Nana. 2010. Penilaian Hasil Proses Belajar Mengajar. Bandung : PT. Remaja Rosdakarya.

Sugilar, Hamdan. 2013. Meningkatkan Kemampuan Berpikir Kreatif Dan Disposisi Matematik Siswa Madrasah Tsanawiyah Melalui Pembelajaran Generatif. [online] Jurnal Ilmiah Program Studi Matematika STKIP Siliwangi Bandung, Vol 2, No 2, September 2013.

Suherman, E, at al. 2003. Common textbook Strategi Pembelajaran Matematika Kontemporer. Bandung: JICA UPI.

Sulistiowaty. 2013. Upaya Meningkatkan Kemampuan Pemecahan Masalah Matematika Melalui Model Problem Based Learning pada Siswa Kelas VII-B SMP Swasta PAB 18 Medan. Medan : Universitas Negeri Medan, Skripsi, FMIPA, Unimed.

Sumiati dan Asra. 2013. Metode Pembelajaran. Bandung : CV. Wacana Prima.

Trianto. 2013. Mendesain Model Pembelajaran Inovatif-Progresif. Jakarta : Kencana. Undang-Undang RI Nomor 20 Tahun 2003 Tentang Sistem Pendidikan Nasional Pasal 3. 